\title{
Simulasi Mitigasi Bencana Gempabumi di Sekolah Dasar
}

\author{
Syahrial Ayub $^{1 *}$, Kosim $^{1}$, I Wayan Gunada ${ }^{1}$, Endang P Handayani ${ }^{2}$ \\ ${ }^{1}$ Program Studi Pendidikan Fisika, FKIP Universitas Mataram, Mataram, Indonesia \\ ${ }^{2}$ Dinas Pendidikan Kota Mataram, SD Negeri 6 Mataram, Mataram, Indonesia
}

DOI: https://doi.org/10.29303/jpmsi.v3i1.112

Citation: Ayub, S., Kosim, K., Gunada, I. W., Handayani, E. P. 2021. Simulasi Mitigasi Bencana Gempabumi di Sekolah Dasar. Jurnal Pengabdian Masyarakat Sains Indonesia (JPMSI). 3(1):206-212.

Article history

Received: May $15^{\text {th }} 2021$

Revised: May $30^{\text {th }} 2021$

Accepted: June $17^{\text {th }} 2021$

*Corresponding Author:

Syahrial Ayub,

FKIP Universitas Mataram,

Mataram, Indonesia;

Email:

syahrial_ayub@unram.ac.id

\section{Pendahuluan}

Lombok sebagai salah satu pulau di wilayah Indonesia yang sangat rentan terjadinya gempabumi. Baru baru ini di tahun 2018 antara bulan Juli sampai Agustus pulau Lombok diguncang 4 kali gempa bumi berkekuatan besar, yaitu 29 Juli 2018 kekuatan 6,4 SR, 5 Agustus 2018 kekuatan 7 SR, 9 Agustus 2018 kekuatan 6,2 SR dan 19 Agustus 2018 berkekuatan 7 SR ditambah dengan rentetan gempa susulan yang mencapai 2500 kali. Hal ini terdampak luar biasa pada masyarakat di pulau Lombok terutama di daerah pantai, pegunungan dan perkotaan. Ditandai dengan hancurnya bangunan dan infrastruktur di daerah yang terdampak dan yang sangat memilukan adalah terdapatnya korban ratusan korban jiwa pada rentetan gempa Lombok ini. Hasil observasi dan studi pendahuluan menunjukkan bahwa masyarakat kurang siap dan mitigasi bencana gempabumi belum terlaksana dengan baik.

Gempa bumi merupakan bencana alam yang tidak dapat diprediksi kapan terjadi nya (Ayub, S. 2019). Gempa bumi bisa terjadi tiba-tiba seperti saat bekerja, tidur, bermain, dan bahkan juga saat belajar di sekolah (Disaptono, 2005). Peserta didik adalah kelompok yang paling rentan menjadi korban gempa bumi demikian juga guru dan perangkat sekolah lainnya. Maka dari itu mereka sangat perlu dibekali konsep proses terjadinya gempa bumi, dampak gempabumi dan langkahlangkah penyelamatan diri dari gempa bumi terutama bila gempabumi terjadi saat peserta didik sedang belajar di kelas. Mengajarkan sesuatu yang baru kepada anak-anak tentu membutuhkan metode yang tepat, efektif dan menyenangkan (Djamarah, 2005).

Kegiatan ini, memberikan contoh nyata (simulasi) tentang langkah-langkah penyelamatan 
Ayub et al, Jurnal Pengabdian Masyarakat Sains Indonesia 2021, 3 (1): 206-212. DOI: https://doi.org/10.29303/jpmsi.v3i1.112

diri dari kelas bila terjadi gempabumi saat mereka sedang belajar. Selama kegiatan, guru semestinya membantu peserta didik untuk aktif dalam mencari konsep, prinsip dan fakta bagi dirinya sendiri, bukan hanya memberikan ceramah dan mengendalikan kelas (teachers oriented), dengan demikian peserta didik akan mampu untuk membangun pengetahuannya sendiri (Muryani, 2015). Mitigasi bencana pada peserta didik, guru dan kepala sekolah akan muncul dari proses pembelajaran mitigasi yang dilaksanakan. Tanpa ada proses ini mustahil kesiapsiagaan bencana akan terpatri pada mereka sehingga tujuan utama untuk mencapai masyarakat sadar bencana akan sulit (Klinger, 1997).

Keterampilan proses sains sebenarnya menjadi dasar pendekatan saintifik di kurikulum 2013. Salah satu kegiatan yang dapat diambil guru adalah melakukan praktek (Ramdhani, 2005). Praktek, peserta didik dapat memperoleh pengalaman langsung mengenai kebencanaan dan kesiapsiagaan. Peserta didik akan lebih mudah mengingat suatu konsep bencana jika ia melihat langsung. Peserta didik bahkan tidak hanya sekedar mengingat tetapi mengerti suatu konsep bencana jika ia mengalami sendiri. Melalui praktek, peserta didik dapat menemukan masalah sekaligus mencari jawaban atas masalah yang ditemukan. Masalah yang muncul melalui praktek merupakan sumber ransangan yang sangat potensial untuk belajar lebih banyak. Dengan praktek akan terjadi proses belajar yang punya kandungan ilmiah yang berbobot (Suprapto, 2002).

Masalah akan dipecahkan sendiri lewat praktek tanpa perlu ceramah teoritis dari gurunya. Melalui praktek, peserta didik dapat juga dilatih untuk menggunakan metode-metode ilmiah sederhana yang sahih seperti halnya seorang ilmuwan (Hamidah, 2018). Kegiatan pengabdian ini didasarkan pada hasil penelitian, pengalaman dan pengamatan pembelajaran kebencanaan di kelas menggunakan pendekatan saintifik dengan praktek (Ivers, 2002). Permasalahan yang menarik adalah bagaimana menanamkan langkah-langkah penyelamatan diri dari kelas bila terjadi gempabumi saat mereka sedang belajar.

\section{Metode}

Kegiatan pengabdian ini, menempuh langkah langkah sebagai berikut:
e-ISSN : 2715-2537

p-ISSN : 2715-2545

1) Memberikan pembelajaran bagi peserta didik dan guru SD Negeri 6 Mataram tentang pengetahuan gempa bumi, tanda-tanda, dampak, resiko dan upaya mengurangi, kesiapsiagaan dan mitigasi, dan prosedur pertolongan pertama pada korban gempa bumi. Demontrasi dan simulasi tentang mitigasi gempa bumi dan prosedur pertolongan pertama pada korban gempa bumi.

2) Diskusi dan tanya jawab dengan peserta didik dan guru SD Negeri 6 Mataram tentang langkah-langkah penyelamatan diri dari bencana gempabumi bila terjadi saat peserta didik belajar di dalam kelas.

3) Pemutaran video tentang mitigasi gempa bumi dan dan langkah-langkah penyelamatan diri dari bencana gempabumi bila terjadi saat peserta didik belajar di dalam kelas.

4) Melakukan simulasi penyelamatan diri dari bencana gempabumi bila peserta didik sedang berada di dalam kelas

5) Menyanyikan lagu tentang bencana gempabumi bersama peserta didik dan guru guru di kelas sambil mempraktekkannya.

Sebelum pelaksanaan kegiatan pengabdian ini, tim melakukan beberapa tahapan persiapan, yaitu:

\section{Tahap Pertama}

Pada tahap pertama dilakukan penggalian informasi tentang mitigasi bencana gempabumi kepada peserta didik dan guru. Penggalian informasi ini didapat melalui angket peserta didik dan guru. Data studi awal dan literatur tentang kesiapsiagaan bencana gempabumi juga menjadi informasi awal dalam mengimplementasikan pada kegiatan pengabdian.

2. Tahap Kedua

Tahap ke kedua berdasarkan studi awal dan literatur yang sudah dianalisis, tim mendefenisikan keterampilan melalui perangkat pembelajaran yang dikembangkan dengan merumuskan terlebih dahulu kemampuan dan tujuan khusus yang ingin dicapai.

3. Tahap Ketiga

Pada tahap ini baru disusun draft awal rencana pelaksanaan pembelajaran mitigasi gempabumi yang akan menjadi cikal bakal kegiatan simulasi penyelamatan diri dari bencana gempabumi. Pada tahap ini pula tim melakukan persiapan dokumen pendukung dan alat-alat pendukung untuk tahap implementasi. 
Ayub et al, Jurnal Pengabdian Masyarakat Sains Indonesia 2021, 3 (1): 206-212 DOI: https://doi.org/10.29303/jpmsi.v3i1.112

4. Tahap Keempat

Tahap keempat tim melakukan implementasi pembelajaran dengan melakukan simulasi langkah-langkah penyelamatan diri dari gempabumi di kelas dengan pedoman rencana pelaksanaan pembelajaran yang sudah dibuat.

5. Tahap Kelima

Tahap kelima berdasarkan observasi, evaluasi yang dilakukan oleh tim dan guru serta refleksi yang sudah di implementasikan berulang sesuai indikator yang telah ditetapkan. Observasi dan evaluasi penting dilakukan untuk memperbaiki kualitas pembelajaran (Ibrahim, 2000)

\section{Hasil dan Pembahasan}

Model pembelajaran kesiapsiagaan dikembangkan berdasarkan pendekatan-pendekatan yang diuraikan sebelumnya. Terdapat 3 tahapan pokok pada pembelajaran mitigasi bencana gempabumi ini, yaitu: (1) kegiatan awal, (2) kegiatan inti, dan (3) kegiatan pemantapan. Masing-masing kegiatan pada tahapan pokok ini mempunyai tujuan tertentu.

\section{Kegiatan Awal}

Kegiatan awal pada pembelajaran kesiapsiagaan gempabumi bertujuan memotivasi peserta didik sehingga peserta didik tertarik, ingin mengikuti materi pembelajaran kesiapsiagaan gempabumi yang akan dilakukan. Hal ini sangat penting dilakukan untuk memunculkan kerinduan peserta didik belajar terutama tentang kesiapsigaan bencana. Ada banyak alternatif kegiatan yang dapat dilakukan guru untuk memotivasi peserta didik. Alternatif kegiatan yang dapat dipilih oleh guru pada kegiatan awal adalah: (1) demo sesuatu yang dibawa/guru, (2) pemutaran video, (3) bercerita/kejadian, (4) bernyanyi (sesuai dengan materi kebencanaan yang diberikan), (5) Review/melanjutkan pelajaran terdahulu yang tidak lengkap, (6) mengamati/membahas penerapan teknis di lingkungan, (7) menyajikan fenomena, (8) menggali pengetahuan awal peserta didik, dan (9) bisa juga menampilkan poster/gambar tentang bencana.

Intinya dari kegiatan awal yang dirancang guru ini, peserta didik mampu secara mandiri menemukan permasalahan pembelajaran yang akan diajarkan. Bila masalah itu ditemukan sendiri oleh peserta didik diharapkan peserta didik akan tertarik dan termotivasi untuk melaksanakan pembelajaran
e-ISSN : 2715-2537

p-ISSN : 2715-2545

selanjutnya. Sebagai contoh, untuk membuat peserta didik tertarik guru mempersiapkan pemutaran video tentang proses terjadinya gempabumi dan dampak yang ditimbulkannya.Video yang diputar diambil dari link

https://m.facebook.com/story.php?story_fbid=1231 891816952572\&id=190650671076697. Setelah pemutaran video guru mengajukan beberapa pertanyaan yang mampu menggiring peserta didik pada permasalahan pembelajaran. Contoh pertanyaan yang diajukan guru adalah

a. Bencana alam yang sering terjadi di Indonesia adalah gempabumi, kata gempabumi tentu sudah tidak asing bagi kalian. Apakah yang dapat kalian rasakan atau lihat jika terjadi gempabumi?

b. Kita merasakan getaran dan goyangan, benda yang tadinya tidak bergerak menjadi bergerak. Apakah benda benda itu bergerak sendiri?

c. Pada waktu gempa terjadi, kalian berada dimana? Sedang apa? Dan dapatkah gempa terjadi di saat kalian belajar di kelas ?

Guru menjelaskan dengan gambar Lombok merupakan pulau yang sangat rentan dengan gempa. Pulau Lombok dikelilingi oleh beberapa sumber gempa, yaitu diantaranya Zona Back Arc Thrust di wilayah Utara, Megathrust di Selatan, dan sistem sesar geser di sisi Barat dan Timurnya

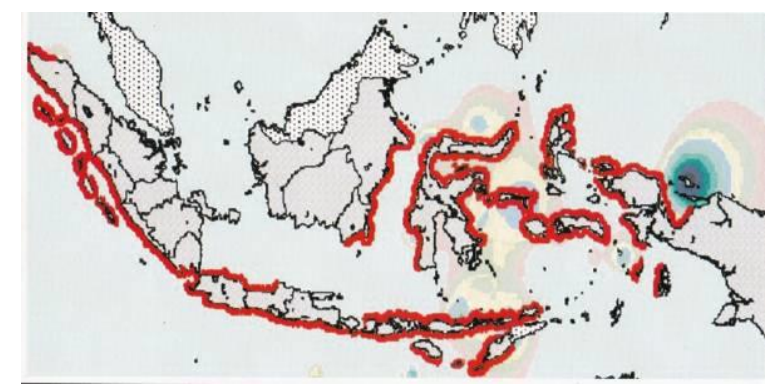

Gambar 1: Lempeng aktif di Indonesia

Diharapkan dari pertanyaan-pertanyaan dan penjelasan ini, peserta didik akan terpancing untuk bertanya:

a. Apakah dampak yang ditimbulkan oleh gempabumi?

b. Bagaimana langkah-langkah penyelamatan diri bila terjadi gempa saat kita belajar di kelas?

\section{Kegiatan Inti}

Permasalahan yang muncul diakhir kegiatan awal, mengindikasikan seorang guru mulai melangkah pada kegiatan inti. Permasalahan itu 
Ayub et al, Jurnal Pengabdian Masyarakat Sains Indonesia 2021, 3 (1): 206-212. DOI: https://doi.org/10.29303/jpmsi.v3i1.112

jangan dijawab oleh guru, tapi cukup ditampung saja, beri penghargaan lebih baik. Guru hanya mengarahkan peserta didik, untuk menjawab permasalahan ini, kita lakukan kegiatan berikut.

Pada kegiatan inti pada pembelajaran kesiapsiagaan gempabumi, yang perlu diperhatikan adalah sebelum terjadi bencana, saat terjadi bencana, proses penyelamatan diri dari bencana, saat sampai di daerah aman, dan saat pertolongan pertama pada korban. Alternatif kegiatan yang dapat dipilih oleh guru adalah: (1) melaksanakan praktek, (2) permainan/simulasi, (3) klasifikasi/pengelompokan, (4) Periksa peta evakuasi, (5) periksa alat teknis pertolongan pertama pada korban, dan (6) menganalisis gambar/foto. Gambar 2 memperlihatkan foto-foto kegiatan pengabdian di SD Negeri 6 Mataram berupa simulasi penyelamatan diri dari bencana gempabumi saat di kelas.
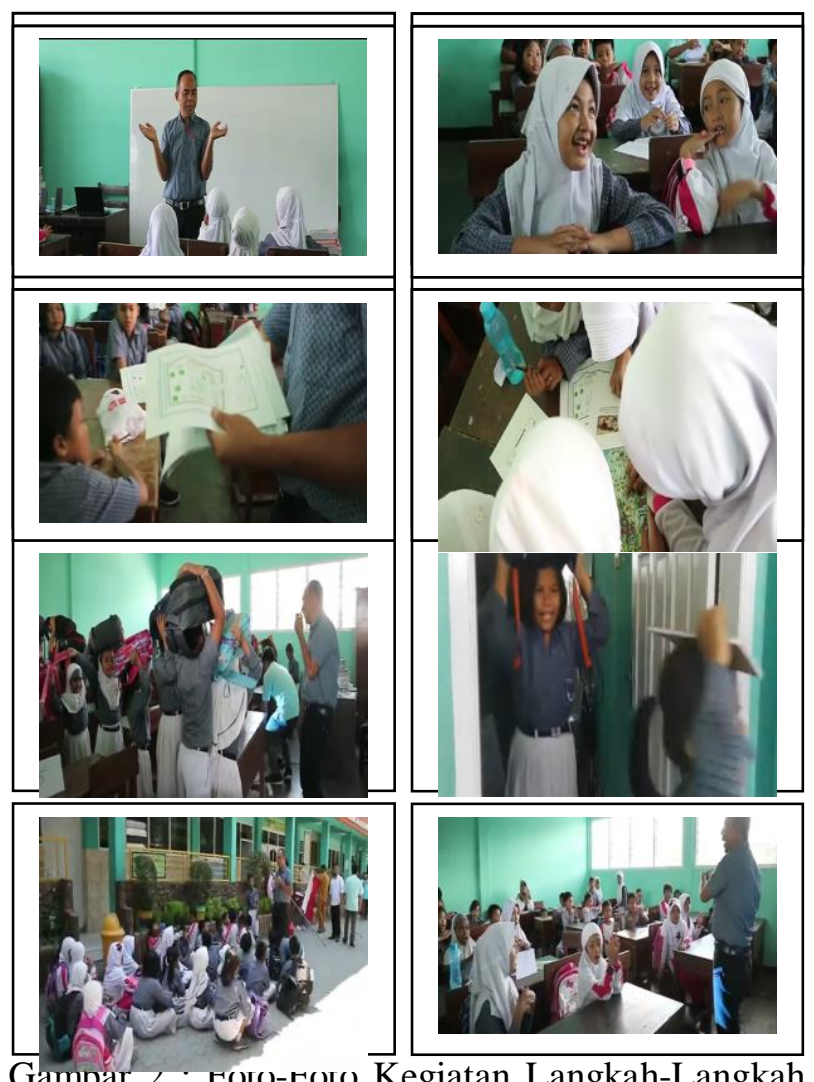

Gamoal 2 : roiv-гuı Kegiatan Langkah-Langkah Penyelamatan Diri dan Dampak Gempabumi di Kelas

Kemudian guru meminta beberapa kelompok mempresentasikan hasil diskusi kelompoknya. Pada proses ini, peserta didik diharapkan berpartisipasi aktif dan melakukan pengamatan sebanyak mungkin. Berdasarkan penjelasan oleh peserta didik (tebak-duga-diskusi) dan landasan pemikiran
e-ISSN : $2715-2537$

p-ISSN : 2715-2545

diharapkan peserta didik mampu menarik kesimpulan sendiri. Setelah kesimpulan didapat oleh peserta didik, permasalahan yang muncul diawal kegiatan inti akan terjawab sendiri. Peserta didik yang akan merasakan sendiri jawabanjawaban mereka diawal kegiatan inti tadi benar atau salah. Jadi tidak guru yang membenarkan atau menyalahkan. Proses ini yang membuat pembelajaran kesiapsigaan bencana menjadi menyenangkan, membuat penasaran dan inovatif. Untuk lebih memantapkan konsep yang didapatkan guru bersama peserta didik menyanyikan lagu langkah-langkah penyelamatan diri dari gempabumi bila terjadi saat belajar di kelas. Lagu tersebut terdapat di youtube dengan https://www.youtube.com/watch?v=cQOuKpzLgL E.

Lirik lagunya adalah:

Kalau ada gempa

Lindungi Kepala

Kalau ada gempa

Jauhilah kaca

Kalau ada gempa

Bersiaplah antri

Berbaris keluar

Kumpul di lapangan

Irama lagu adalah pelangi-pelangi

AT Mahmud

\section{Kegiatan Pemantapan}

Pada kegiatan pemantapan guru melakukan simulasi langkah-langkah penyelamatan diri dari kelas bila terjadi gempabumi. Proses simulasi dapat dilihat pada video kegiatan pembelajaran kesiapsiagaan gempabumi di SD Negeri 6 Mataram. Video sudah tim peneliti share di youtube:

https://www.youtube.com/watch?v=TIKA0ga2vJ8

$\underline{\mathrm{t}=1 \mathrm{~s}}$. Untuk mengakhiri pembelajaran kesiapsiagaan gempabumi ini guru kembali mengajak peserta didik bersama sama menyanyikan lagu siaga bencana, dengan lirik :

Tinggal di Indonesia

Bersama banyak gempa

Tsunami juga ada

Di desa dan di kota

Ayo kita siaga

Agar slamat semua

Lekas-lekas pahami tandanya

Kalau gempa melanda

Lindungilah kepala

jauhi dari kaca 
Ayub et al, Jurnal Pengabdian Masyarakat Sains Indonesia 2021, 3 (1): 206-212. DOI: https://doi.org/10.29303/jpmsi.v3i1.112

Masuklah kolong meja

Saat gempa mereda

Lari ke tempat terbuka

Jangan lupa bawa tas siaga

Jika gempa terasa

Tiga puluh detik lamanya

Kuat lemah tak beda

Tsunami bisa ada

Ajak sluruh keluarga

Ke tempat aman sementara

Tiga puluh menit waktu tersisa

Ayo berlari saja

Tinggalkan mobil semua

Ke tempat yang kita bisa

Tiga puluh meter tingginya

Jika kita di sana

Tsunami tak berdaya

Semoga selamat sejahtera semua

Irama lagu adalah : becak karangan Ibu Sud

Pada kegiatan pemantapan ada beberapa hal yang harus dibahas oleh guru, yaitu : (1) penerapan (berhubungan dengan lingkungan peserta didik), (2) menjawab pertanyaan, (3) membuat ringkasan, dan (4) memberikan pekerjaan rumah. Bila kita kaitkan alur pembelajaran ini dengan pendekatan saintifik, sangat sesuai dengan tahapan-tahapannya. Ada 6 tahapan pendekatan saintifik, yaitu: (1) Mengamati, (2) Menanya, (3) Mengumpulkan Informasi, (4) Mengasosiasi, (5) Menyimpulkan, , (6) Mengkomunikasikan (Huda, M. 2013).

Pelaksanaan kegiatan simulasi langkahlangkah penyelamatan diri dari bencana gempabumi bagi peserta didik dan guru SD Negeri 6 Mataram dilaksanakan pada hari Sabtu tanggal 8 Agustus 2019. Berdasarkan pengamatan langsung dan wawancara yang dilakukan terungkap bahwa kegiatan ini sangat bermanfaat karena telah memberikan pengetahuan dan contoh nyata tentang gempa bumi, langkah-langkah penyelamatan dir dari bencana gempabumi dan mitigasi dan serta prosedur pertolongan pertama bagi korban gempa. Peserta didik berharap kegiatan ini dapat dilanjutkan secara kontinu dan lebih optimal lagi. Secara umum, semua peserta didik yang berjumlah 32 orang dan 2 orang guru, mengikuti pelaksanaan simulasi secara sungguh-sungguh, baik dalam mendengarkan informasi maupun dalam melakukan praktik-praktik yang diberikan.

Materi pengabdian yang disampaikan ada enam, yaitu pengetahuan tentang kegempa-an, tanda-tanda akan terjadi gempa, dampak yang

\begin{abstract}
e-ISSN : 2715-2537
p-ISSN : 2715-2545

ditimbulkan, resiko dan upaya mengurangi, kesiapsiagaan dan mitigasi, dn prosedur dan alat pertolongan pertama pada korban. Informasi disampaikan dengan metode ceramah, simulasi, diskusi kelas dan tanya jawab. Seluruh kegiatan simulasi dapat diikuti dengan baik oleh seluruh peserta didik. Tampak bahwa sebagian besar peserta didik sudah memiliki pengetahuan untuk penyelamatan diri ketika terjadi gempa. Hal tersebut dapat dilihat dari kecepatan mereka menerima dan mengikuti petunjuk yang diberikan. Misalnya, ketika mereka dilatih untuk berlindung di bawah meja saat terjadi gempa, dalam waktu singkat mereka bisa melakukannya dengan baik.
\end{abstract}

\section{Kesimpulan}

Kegiatan pengabdian pada masyarakat berupa simulasi penyelamatan diri dari bencana gempabumi bila peserta didik dan guru berada di dalam kelas saat belajar di SD Negeri 6 Mataram sangat bermanfaat bagi peserta karena memberikan pengetahuan teoritis dan praktek tentang pengetahuan tentang kegempa-an, tanda-tanda akan terjadi gempa, dampak yang ditimbulkan, resiko dan upaya mengurangi, kesiapsiagaan dan mitigasi, dan prosedur dan alat pertolongan pertama pada korban. Hal ini akan meningkatkan kesadaran dan tanggap terhadap bencana alam terutama gempa bumi di sekolah dasar sehingga diharapkan mampu meminimalkan dampak negatif dari gempa bumi.

\section{Saran}

Kegiatan ini sebaiknya lebih sering dilakukan dan melibatkan komunitas sekolah yang lebih banyak, sehingga langkah-langkah yang tepat penyelamatan diri dari bencana gempabumi bila terjadi di sekolah menjadi prilaku yang sudah tertanam pada komunitas sekolah.

\section{Ucapan Terima Kasih}

Terima kasih kami ucapkan kepada kepala sekolah SD Negeri 6 Mataram beserta bapak/ibu guru atas segala bantuan dan partisipasi mereka sehingga kegiatan pengabdian kepada masyarakat ini terlaksana dengan baik dan lancar. Kepada LPPM Universitas Mataram melalui Fakultas Keguruan dan Ilmu Pendidikan yang telah memberikan dana untuk kegiatan ini. 
Ayub, S. Kosim. Gunada. 2019. Tsunami. Gunung Sari West Lombok : Arga Puji

Diposaptono S. 2005. Tsunami Mitigation Technology. Jakarta: Republic of Indonesia Maritime and Fisheries Agency Tsunami Mitigation Training Material.

Djamarah. 2005. Teachers and Students in Educative Interaction, A Psychological Theoretical Approach. Jakarta: Rineka Cipta.

Huda, M. 2013. Teaching and Learning Model Models of Methodical and Pragmatic Issues. Yogyakarta: Pustaka Pelajar.

Hamidah, Gunawan, \& Muhammad Taufik. "Effect of Media Assisted Discovery Learning Model on Physics Learning Outcomes of Class XI Students of SMA N 1 Kediri Academic Year 2017/2018”. Jurnal Pendidikan Fisika dan Teknologi, Vol. 4 No. 1, h. 78-86, Juni 2018.

Ibrahim. Muslimin. 2000. Problem Based Learning. Surabaya: University Press.

Ivers, Baron. 2002. Multimedia Projects in Education Designing Producing and Assesing. New York: John Willey \& Sons.

Klinger, Walter. 1997. Survey of Teaching Methods in Natural Sciences Erziehungswiss. Fakultat der Universtat: Erlangen-Nurnbe.

Muryani, A.D., \& Rochmawati. 2016. "Differences in Student Learning Outcomes Using Assisted Discovery Learning Learning Models and Without Assistance to Student Worksheets". Jurnal Pendidikan Ekonomi, Vol. 1 No.1, h. 713, Maret 2016.

Suprapto S. 2002. Flood Disaster, Material for Disaster Power Training. Yogyakarta : PSBA UGM.

Ramdhani A. 2005. Optimization of Physics Learning with the Use of Science Kits at SMP N 6 Mataram. Mataram: Press Unram,. 